Henrik Jochumsen*

\title{
How to Qualify the Debate on the Public Library by the Use of Research-Developed Tools
}

https://doi.org/10.1515/bfp-2018-0041

\begin{abstract}
The article discusses how it is possible to qualify the debate on public libraries by the use of research based models and concepts and hereby maybe even change the crisis discourse that according to the author characterizes the public debate on current library development. Keyelements are the four-space model, the three-function model and the concept of "New Librarianship".
\end{abstract}

Keywords: Public Libraries; library development; library debate

\section{Wie kann die Debatte über die öffentliche Bibliothek durch den Gebrauch von forschungsbezogenen Werkzeu- gen qualifiziert werden?}

Zusammenfassung: Der vorliegende Aufsatz versteht sich als Bereicherung der Debatte über die öffentlichen Bibliotheken durch den Gebrauch forschungsbasierter Modelle und Konzepte. Es werden dazu drei solcher Modelle/ Konzepte diskutiert (das Vier-Raum-Modell, das DreiFunktionen-Modell und das Konzept des „New Librarianship") und die Möglichkeiten ausgelotet, wie sie dazu helfen können, den Krisendiskurs zu überwinden, der die öffentliche Debatte in hohem Maße prägt.

Schlüsselwörter: Öffentliche Bibliotheken; Bibliotheksentwicklung; Bibliotheksdebatte

\section{Introduction}

In Denmark, we are often confronted with the claim that the public library is in at state of crisis. If we look solely at lending figures, we will find that these are certainly decreasing. But if we look at the number of visitors in the libraries, we see that the number is actually increasing. ${ }^{1}$ If we instead look at public spending on libraries, we see a significant decline in the library budgets of the munici-

1 Slots og kulturstyrelsen (2015).

*Kontaktperson: Dr. Henrik Jochumsen, hjo@hum.ku.dk palities $^{2}$, but at the very same time we experience that new and often very headline grabbing libraries are being built in different parts of the country. The public library in Aarhus, Dokk1, is a very good example. Therefore, whether the public library is actually in a state of crisis very much depends on what we choose to focus on. The glass might be half-filled just as well as it might be halfempty. It is in the eyes of the beholder.

However, there is no doubt that it is possible to identify a crisis discourse when looking at the debate on public libraries in Denmark. In public debate, for instance, libraries are often dealt with from a rather critical point of departure concerning the current development in the libraries. Focus is mostly on reduction of collections in favor of other utilization of the library space or on the development of new and for the public not always immediately understandable offers in the library. This was clearly expressed when the Danish neoliberal think tank CEPOS in the autumn of 2017 published a working paper. Here they demonstrated how the expenses connected to the lending of books in public libraries have increased significantly due to the decrease in lending figures. ${ }^{3}$ In others words, the costs per lending had exploded as lending are significantly fewer. The think tank is fully aware that the public library today has made a transformation from "collection to connection" and that it now offers a very wide range of user-oriented activities such as literature events, makerspaces, writing workshops, debates, and user driven reading circles etc. to the citizens. Thus, the aim of the working paper was clearly to demonstrate that these kinds of activities, in the eyes of the think tank, represent a state funded competition to private business at best or just a needless waste of public money at worst. This neoliberal viewpoint does not stand alone with its criticism. Conservative voices that wish to recreate the public library as a more traditional collection of books do happily support. Although the first viewpoint wants to minimalize the public library and the second to "restore" the public library both viewpoints, look solely upon the collection of books as the aim and reason d'être of the public library.

2 Ibid.

3 Christoffersen and Larsen (2017). 
A public debate on the library is certainly not a bad thing. On the contrary, it forces library professionals to sharpen the arguments concerning the relevance of the library as a publicly funded institution. It also forces the library professionals to demonstrate how and why concepts like "connection", "user participation" and “(co) creation" might represent means for building, enlightenment, and social mobility in the age of digitalization and globalization just as the knowledge found in books did in the age of industrialization and democratization. Add to this the need to explain how and why the library as a community based noncommercial place and space open for all citizens might have a potential to support coherence in a society increasingly divided by ethnicity and income level. To be part of this debate or maybe even to change the discourse, demands a much more offensive and targeted approach than normally seen in the often rather retained library field. The crisis discourse, concerning the public library is by no means restricted to be a national Danish phenomenon. Nevertheless, it is of particular importance in a Danish context as the Danish library act is likely to be revised soon. Thus, the Danish minister of culture - who by the way represents a neo-liberal political party - has announced that she will start a preparatory work during the spring of 2018.

\section{This article}

The question I would like to address in this article is how different research-based approaches can contribute to qualify and support the debate on the public library. It is my point of departure that the crisis discourse does no good as an overall frame for a serious and constructive debate as it tends to place both the library and the library professionals in a rather defensive position. At the same time it might - as any discourse - construct "reality" and in the case of the public library leave the glass nothing but half-empty.

In the following, I will emphasize three different "tools", which might be useful to qualify the debate on the public library as they might be supportive for a less retained approach. The first two tools are both models created by Dorte Skot-Hansen, Casper Hvenegaard Rasmussen and the author of this article, all three associate professors at the University of Copenhagen. The first model is today commonly known and referred to in library circles as "The four-space model". The second might be lesser known but is sometimes referred to as the "The three-function model" which also is the term I use in the following. Both models have been developed as research based theoretical tools meant to shed light on the current library development as well as to qualify the discussion on the library. Since the development of the two models in 2010 and 2011, respectively, not least, "The four-space model" has been widely used not only to increase the understanding of the current library development but also as a concrete tool used in the planning, building, and policy-making related to public libraries.

The third tool I will deal with is the concept of "New Librarianship" as developed by the American library researcher and professor R. David Lankes from the University of South Carolina. ${ }^{4}$ This concept is currently being discussed in the library field worldwide. Briefly it represents a shift in focus from the library as an institution towards the library as the result of the librarians engaged in the library. Thus, as the two first mentioned models deal with the libraries as institutions, the concept of "New Librarianship" looks upon libraries as the effort of the librarians.

\section{Why crisis discourse}

The crisis discourse, characterizing the current library debate, may be due to many different circumstances. In the following, I pinpoint four of these, which I find particular important. Analytically these circumstances can be looked upon separately, but in reality, they are indeed intertwined. It concerns the digital development, the relationship between legitimacy and identity, the challenges coming from the so-called "experience society", and finally, it concerns the development of what the English sociologist Anthony Giddens refers to as "the radical reflective society". ${ }^{5}$ As space is limited, I will only be able to touch upon these issues in a rather superficial manner.

One of the most significant reasons behind the crisis discourse in the library debate is without doubt related to digitization. Thus, it is not difficult to point out how digitization of books, music, and information has led to a significant decline in lending figures. Literature, music experiences as well as information of all kind is accessible from our digital platforms 24/7. This has not surprisingly initiated a debate on the overall relevance of the physical and community based public library. If everything is available always and everywhere (and to some extent for free) then do we really need public libraries at all? The answer

4 See e.g. Lankes $(2011,2016)$ and his article in this volume pp. 338-43.

5 Giddens (1991). 
from the previously mentioned Danish neoliberal think tank would most likely be that public library service could easily be reduced to a digital and national centralized library solution concentrating only on hard to find material. The answer of the public libraries to the digital development has in fact been quite the opposite as library professionals have searched high and low for new offers that could be integrated in the library; from lending of tools and fishing gears to baby massage and printing of t-shirts. Some of these new offers might be relatively familiar to the traditional role of the public library. Others may be very far from what the public expects from a library. However, independent of the immediate or self-evident relevance of the various new offers the big span in these offers creates a discrepancy between the legitimacy and the identity of the library. Thus, the more library professionals seek to create legitimacy by including a wide range of not always obvious offers the more a clear and distinct identity of the library might be less clear. On the other hand, the more the library tries to keep a strict identity as a traditional and collection-oriented institution the more the legitimacy is under attack by the competition from digital offers and commercial providers.

This "catch-22-situation" is nothing but supported by the increased competition, which characterizes the socalled "experience-society" or "experience-economy" Both concepts refer to a situation in which traditionally experience-generating institutions, like e.g. museums, art galleries, and libraries have to fight very hard for getting attention among a wide range of commercial offers. This is not just about an explosively growing entertainment industry but also refers to the fact that all kinds of commercial goods are now connected to some kind of experiences. Factors like price, quality, or service can no longer stand alone as arguments for buying the products. The result might be that the more traditional cultural offers drown in a "sea of experience".

The last thing I would like to include is the development of the radical reflective society. According to Giddens late modernity (the period from the 1960's and forward) is characterized by an absence of traditions. Thus, traditions, which formerly were connected to a religious or later a (positivistic) scientific approach to the world, do no longer frame our existence or actions. The absence of traditions creates the foundation for a state of radical reflection in which we as individuals are forced to constantly reflect on our own choices and possibilities. In our context, what is

6 Schulze (1994).

7 Pine and Gilmore (1999). interesting is that this development does not only apply to us as individual human beings but to institutions like the public library as well. In other words: what Giddens provides is a sociological explanation of why library professionals are trying so hard to legitimize the library by including offers that points in every possible direction. It is quite simple no longer given what a library is or what it should offer to the citizens.

All of the above-mentioned circumstances contribute to create the crisis discourse as well as to place the library professionals in a position from which they have to constantly defend the current development of the public library. At the same time, this position of permanent self-defense seems to prevent them from explaining how and why the development including all the different offers and diverse activities may express the aim of the library to the benefit of the citizens. On basis of this, it is quite evident that other tools to qualify the library debate are needed.

\section{The four-space model}

The "four-space model" was created in 2010 on behalf of the Committee on Public Libraries in the Knowledge Society appointed by the Danish Minister of Culture. ${ }^{8}$ The background for the committee was the closure of a large number of library branches due to a reform of the municipal structure in Denmark. Thus, the committee was asked to consider new concepts for the public library.

The four-space model as shown below was created primarily on two conditions. On the one hand, it was based on analyses of the current development of the public library. This development demonstrated a significantly transformation from a focus on the collections to a focus on the library as a space for relations, connections or cocreation with the users. On the other hand, it was created on the basis of analyses of societal development inspired by leading sociologists such as Zygmunt Bauman (1998) and Anthony Giddens (1991) concerning tendencies towards globalization, de-traditionalization, cultural liberation, and development towards a multicultural society and lack of social cohesion. Seen in the light of both library internal and external factors the development of a new library model was needed that took into account the challenges of societal development as well as highlighted the potentials of the library. ${ }^{9}$

8 Danish Agency for Library and Media (2010).

9 Jochumsen et al. (2012) 588. 


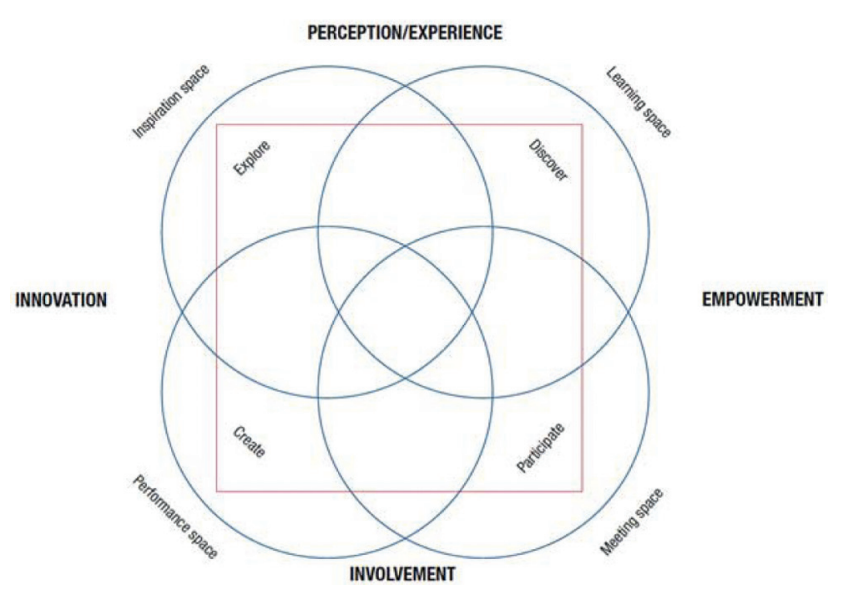

Fig 1: Four-space model

I will not explain the model in detail as this is done thoroughly in several other articles. ${ }^{10}$ Instead, I will limit myself to briefly touch upon the essence of the model. According to the model, the library's overall objective is to support the four following goals: "Experience", "Involvement", "Empowerment", and "Innovation". At the same time the model indicates the possibilities for experiencing, discovering, participating, and creating as the library consists of four different and overlapping "spaces" which are "the inspiration space", "the learning space", "the meeting space", and "the performative space". ${ }^{11}$ Hence, the model aims at a balance between tradition and renewal by combining more classical objectives of the library like learning and empowerment with newer tendencies like participating and innovation.

During almost ten years, the four-space model has proved itself a useful tool when it comes to qualifying the debate on the public library in general and on the library space in particular. Since the four-space model was conceived, it has been widely used among researchers as well as practitioners in the library field. Especially practitioners have used the model for many different purposes such as an instrument for developing, designing, arranging or rearranging libraries or as a management and communication tool in connection to development of library plans and policy. The model has also been used to emphasize and explain the current library development to both politicians and citizens. Partly because of this, concepts like "meeting space", "performative space" or "inspiration space" are now a common part of the library debate.

10 See e.g. Jochumsen et al. (2012, 2014, or 2016).

11 Jochumsen et al. (2012) $589 \mathrm{f}$.
By making the different spaces in the library explicit and by relating the spaces to overall goals, the model stresses why the physical library cannot be replaced by a centralized digital library offer. Thus, the fulfillment of the goals will always be dependent on interaction between the librarians and the users of the library. At the same time, the content of the different spaces as well as their mutual priority will be dependent of the local community. At the same time the model illustrates how various and very different offers might be legitimate in the library without the library losing its basic focus or identity. Thus, the model provides a point of departure from which professionals in the library field are able to explain the development of new and maybe unconventional offers in the library at the very same time as they relates these offers to the overall and normative objectives of the library.

\section{The three-function model}

"The three-function model" was born in 2011 as a result of the Danish research project "Public Library in Urban Development - Creativity, Innovation and Experience". Based on case studies in Europe and North America the aim of the project was to study how new "cutting-edge" libraries contributed to city and community development in different ways. ${ }^{12}$ To explain and visualize the main results of the study the three-function model as it appears below was created.

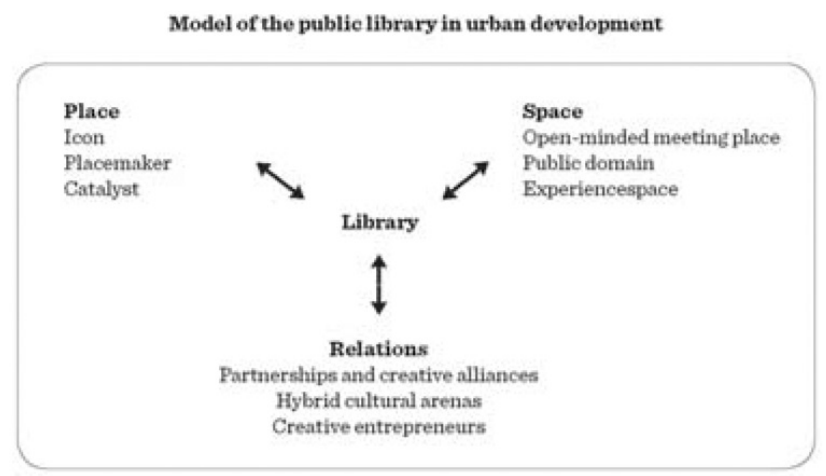

Fig 2: Three-function model

The three-function model describes how public libraries contribute to city and community development in three different ways: as a place, as a space and as the point of

12 The results of the study have been published in e.g. Hvenegaard Rasmussen et al. (2011) and Skot-Hansen et al. (2017). 
departure for relations. It is important to keep in mind that a model is always a reduction of reality and thus to look upon these headlines as a way to synthesize the often very complex relationship between library development and urban development. Again, I will not explain the model in detail but highlight the essence by giving a brief introduction to the meaning of the different concepts contained in the model. Initially, I will concentrate on the headline concepts "Place", "Space", and "Relations". Concerning the library as a Place the focus is how the library can serve as a catalyst for change and urban development. Concerning the library as a Space the focus is how the library can enhance a creative and innovative city as a space for experiences and new meetings. Finally, concerning the library as Relations the focus is on how the library can contribute to synergy, connections, and transformations through new creative partnerships.

The research project made it visible how the library as a Place could serve as a catalyst for change and urban development in primarily three ways. By being a local or even global "icon" that through performative architecture draws the attention from both local citizens and visitors and as such become a symbol of the city or community. By being a "placemaker" which plays an important part when it comes to re-vitalization of city centers or development of new parts of the city. Finally, by being a catalyst for local identity and social coherence and as such contribute to a positive development in otherwise run-down neighborhoods. As a Space, the library can enhance the city by being an "open-minded meeting place" creating a vibrant and including space in the city. Placed between neighborhoods with different social or cultural identities the library can be a "public domain" that contributes to exceed boundaries both physically and socially. Another possibility is to create transitional zones between the inside and the outside of the library. Finally, by being a space for experiences the library can contribute to creativity and innovation in the city or community.

As part of relations in the city or community, the library can be the initiator of "partnerships and creative alliances" and as such support cultural, social, and economic development. The library can also be placed together with other institutions and cultural offer and as part of such so-called "hybrid cultural arenas" support a positive synergy between the institutions to the benefit of the city and citizens. By providing stages and free physical space for activities, the library can finally be an active supporter of the creative and cultural growth layer in the city.

In very much the same way as the four-space model the three-function model creates a platform from where it is possible to emphasize and communicate important aspects of current public library development. Contrary to the four-space model though, the three-function model primarily focus on the relationship between the library and the city or surrounding community. As such, the threefunction model provides the participants in the library debate with focus points concerning the role of the library in city planning and community development. In other words: if we focus on the library as respectively a space, a place or as relations, we are actually able to qualify the discussion of how the physical and locally based library might contribute to a vibrant and livable city or to a coherent community.

\section{New Librarianship}

As shown above both the four-space model and the threefunction model might be useful tools in the qualification of the debate on public libraries. This is especially the case when the aim is to emphasize the objectives, the possibilities, the potentials, and the variety of means connected to the library. However, both models do have certain limitations. As the point of departure for both models is the public library as an institution this somehow tends to neglect those whose competencies, knowledge, and engagement are the very core of all library activities. In other words: no library can be relevant, contemporary, and at the same time actively evolved in the community without librarians. If the crisis discourse is going to be confronted or even changed, we need more than models visualizing or explaining the development of the library or the relationship between the library and the surrounding society. We need to hear the voices of the librarians.

A current and important contribution to the library and information literature that brings the librarians into focus is the concept of "New Librarianship" as developed by R. David Lankes. With this concept, Lankes emphasizes that librarians are in fact part of a mission to make their communities better. As he states: "no matter how different the mission of their libraries, the mission of the librarians remains the same - improving society through facilitating knowledge creation". ${ }^{13}$ One might ask: "what's actually new about New Librarianship?" According to my reading, the answer will be that exactly this mission and not least the awareness of being the one that carry out the mission for far too long has been dismantled into ideas about the neutrality of the librarian. However, the librarian is not

13 Lankes (2016) 19. 
neutral as she or he is an agent for improving society. With great risk of making me guilty of simplification I will argue that Lankes primarily does three things. Firstly, he shows how the history of librarians to a large extend has been told from an institutional perspective. By changing the perspective, the aim is to "release" the librarians from the institution and instead tie the mission of the library to the people who act as librarians in any context. Secondly, he emphasize as stated above that being a librarian is not to be neutral, or just waiting for questions. It is to be a radical (in the sense of far reaching) positive change agent in the community. Thirdly, and in direct extension of the latter, he states that the mission of librarians is to improve society through facilitating knowledge creation in their communities. ${ }^{14}$ In this context, I allow myself to interpret "knowledge creation" in a broad sense including different kind of cultural expressions and experiences.

What is especially relevant in our context is that Lankes highlights an agent perspective, which is entirely missing in most of the current library debate that solely focus on the library as an institution. By embracing the concept of new Librarianship we get a chance to add some flesh and bone to the library debate. Thus, by focusing much more on the librarian the library debate could be improved by voices explaining how and why they make a difference in their community by establishing reading circles, by developing partnerships, by arranging political debates etc. One might assume that the one who makes "a radical positive change" in the community actually is the one most suited to explain both means and goals behind the change.

\section{Conclusion}

As we have seen it might be an issue for discussion whether the public library actually is in a state of crisis or not. However, there is no doubt that it is possible to identity a crisis discourse characterizing public debate on libraries. This crisis discourse may be due to many different circumstances such as digitization, discrepancy between identity and legitimacy and the development of experience society and radical reflective society. The crisis discourse is a major problem, as it tends to leave the library and the library professionals in a defensive position. A position that makes it difficult to explain how and why the current development in the library may express new but relevant library offers for the citizens. To qualify the debate re-

14 Lankes (2016). search based models like are the four-space model and the three-function model may be useful as they provide starting points from which professionals in the library field are able to explain the development to the public. As a supplement to the use of the above-mentioned models, the concept of "New Librarianship" can prove to be very important as it emphasizes that libraries are in fact only libraries because of the librarians making a positive change in the community. Thus, models like the four-space model or the three-function model that illustrate and visualize the development cannot stand alone but need to be given life by the women and men who create the very same development.

\section{References}

Bauman, Zigmunt (1998): Globalisation. The Human Consequences. Cambridge, MA: Policy Press.

Christoffersen, Henrik; Larsen, Carsten Bo (2017): Folkebiblioteker, bøger og andet godt. CEPOS Arbejdspapir 54, 2017. Available at https://www.cepos.dk/sites/cepos.dk/files/media/docu ments/arbejdspapirer/arbejdspapir_54_2/arbejdspapir_54_-_f olkebiblioteker_boeger_og_andet_godt.pdf. Accessed February 4, 2018.

Danish Agency for Library and Media (2010): The public libraries in knowledge society. Summary from the committee on public libraries the knowledge society. Available at https://slks.dk/pu blikationer/publikationsarkiv-styrelsen-for-bibliotek-og-med ier/singlevisning/artikel/the_public_libraries_in_the_knowl edge_society/. Accessed February 4, 2018.

Giddens, Anthony (1991): Modernity and Self-identity. Self and Society in the Late Modern Age. Cambridge: Polity Press.

Hvenegaard Rasmussen, Casper; Jochumsen, Henrik; Skot-Hansen, Dorte (2011): Biblioteket i byudviklingen - oplevelse, kreativitet og innovation. København: Danmarks Biblioteksforening.

Jochumsen, Henrik; Skot-Hansen, Dorte; Hvenegaard Rasmussen, Casper (2012): The four spaces - a new model for the public library. In: New Library World, 113 (11/12), 586-97.

Jochumsen, Henrik; Skot-Hansen, Dorte; Hvenegaard Rasmussen, Casper (2014): Erlebnis, Empowerment, Beteiligung und Innovation: Die neue Öffentliche Bibliothek. In: Eigenbrodt, Olaf; Stang Richard (Hrsg): Formierungen von Wissensräumen. Berlin: De Gruyter, 67-80.

Jochumsen, Henrik; Skot-Hansen, Dorte; Hvenegaard Rasmussen, Casper (2016): The Four Spaces of The Public Library. In: Baker, David; Evans, Wendy (ed.): The end of Wisdom - The Future of Libraries in a Digital Age. Chandos Publishing, 39-44.

Lankes, R. David (2011): The Atlas of New Librarianship. Cambridge: MIT Press.

Lankes, R. David (2016): The New Librarian Field Guide. Cambridge: MIT Press.

Pine, Joseph; Gilmore, James H. (1999): The experience economy Work is a theatre and every business a stage. Boston: Harvard Business School Press.

Schulze, Gerhard (1992): Die Erlebnisgesellschaft. Frankfurt/Main: Campus. 
Skot-Hansen, Dorte; Hvenegaard Rasmussen, Casper; Jochumsen, Henrik (2017): The role of public libraries in culture-led urban regeneration. In: New Library World, 114 (1/2), 7-19. DOI $10.1108 / 03074801311291929$.

Slots og kulturstyrelsen (2015): Folkebiblioteker i tal 2015. København: Kulturministeriet.

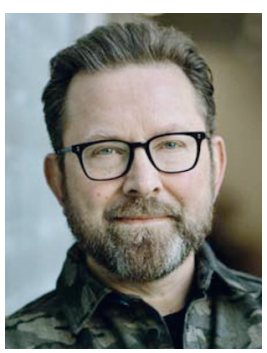

Dr. Henrik Jochumsen Lektor, Associate Professor

Institut for Informationsstudier/Department of Information Studies

Københavns Universitet/University of Copenhagen

South Campus, build. 4

Njalsgade 76

DK-2300 Copenhagen S

Denmark

hjo@hum.ku.dk 